\title{
Front Matter: Volume 6483
}

, "Front Matter: Volume 6483," Proc. SPIE 6483, Complex Light and Optical Forces, 648301 (26 February 2007); doi: 10.1117/12.727382

SDIE Event: Integrated Optoelectronic Devices 2007, 2007, San Jose, California, SPIE. United States 


\title{
PROCEEDINGS OF SPIE
}

\section{Complex Light \\ and Optical Forces}

\author{
David L. Andrews \\ Enrique J. Galvez \\ Gerard Nienhuis \\ Editors
}

24-25 January 2007

San Jose, California, USA

Sponsored and Published by

SPIE-The International Society for Optical Engineering

Volume 6483 
The papers included in this volume were part of the technical conference cited on the cover and title page. Papers were selected and subject to review by the editors and conference program committee. Some conference presentations may not be available for publication. The papers published in these proceedings reflect the work and thoughts of the authors and are published herein as submitted. The publisher is not responsible for the validity of the information or for any outcomes resulting from reliance thereon.

Please use the following format to cite material from this book:

Author(s), "Title of Paper," in Complex Light and Optical Forces, edited by David L. Andrews, Enrique J. Galvez, Gerard Nienhuis, Proceedings of SPIE Vol. 6483 (SPIE, Bellingham, WA, 2007) Article CID Number.

ISSN 0277-786X

ISBN 9780819465962

Published by

SPIE-The International Society for Optical Engineering

P.O. Box 10, Bellingham, Washington 98227-0010 USA

Telephone 1 360/676-3290 (Pacific Time) · Fax 1 360/647-1445

http://www.spie.org

Copyright (C) 2007, The Society of Photo-Optical Instrumentation Engineers

Copying of material in this book for internal or personal use, or for the internal or personal use of specific clients, beyond the fair use provisions granted by the U.S. Copyright Law is authorized by SPIE subject to payment of copying fees. The Transactional Reporting Service base fee for this volume is $\$ 18.00$ per article (or portion thereof), which should be paid directly to the Copyright Clearance Center (CCC), 222 Rosewood Drive, Danvers, MA 01923. Payment may also be made electronically through CCC Online at http://www.copyright.com. Other copying for republication, resale, advertising or promotion, or any form of systematic or multiple reproduction of any material in this book is prohibited except with permission in writing from the publisher. The CCC fee code is 0277$786 \times / 07 / \$ 18.00$.

Printed in the United States of America. 


\section{Contents}

vii Conference Committee

ix Introduction

OPTICAL BINDING AND ATOM TRAPS

648302 Optical trap shaping for binding force study and optimization (Invited Paper) [6483-01]

M. Guillon, Observatoire de Haute Provence (France)

648303 Forces and binding in a two-mirror system [6483-02]

A. Mizrahi, L. Schächter, Technion-Israel Institute of Technology (Israel)

648304 Optical electrostriction [6483-03]

R. G. Crisp, D. L. Andrews, Univ. of East Anglia (United Kingdom)

648305 High-speed dynamic spatial control of cold atoms with combined acousto-optic and spatial light modulation [6483-04]

F. K. Fatemi, M. Bashkansky, Z. Dutton, Naval Research Lab. (USA)

648306 Developments toward atomic quantum sensors [6483-05]

T. van Zoest, T. Müller, T. Wendrich, M. Gilowski, E. M. Rasel, Leibniz-Univ. Hannover (Germany); T. Könemann, C. Lämmerzahl, H. J. Dittus, Univ. Bremen (Germany); A. Vogel,

K. Bongs, K. Sengstock, Univ. Hamburg (Germany); W. Lewoczko, A. Peters, Humboldt-Univ. zu Berlin (Germany); T. Steinmetz, J. Reichel, Lab. Kastler Brossel (France); G. Nandi, W. Schleich, R. Walser, Univ. of Ulm (Germany); W. Ertmer, Leibniz-Univ. Hannover (Germany)

648307 Single-beam dark toroidal optical traps for cold atoms [6483-06]

F. K. Fatemi, S. E. Olson, M. Bashkansky, Z. Dutton, M. Terraciano, Naval Research Lab. (USA)

Pagination: Proceedings of SPIE follow an e-First publication model, with papers published first online and then in print and on CD-ROM. Papers are published as they are submitted and meet publication criteria. A unique, consistent, permanent citation identifier (CID) number is assigned to each article at the time of the first publication. Utilization of CIDs allows articles to be fully citable as soon they are published online, and connects the same identifier to all online, print, and electronic versions of the publication.

SPIE uses a six-digit CID article numbering system in which:

- The first four digits correspond to the SPIE volume number.

- The last two digits indicate publication order within the volume using a Base 36 numbering system employing both numerals and letters. These two-number sets start with 00, 01, 02, 03, 04, 05, 06, 07, 08, 09, 0A, OB ... 0Z, followed by 10-1Z, 20-2Z, etc.

The CID number appears on each page of the manuscript. The complete citation is used on the first page, and an abbreviated version on subsequent pages. 
648308 Analysis of localization phenomena in weakly interacting disordered lattice gases [6483-28]

T. Schulte, S. Drenkelforth, J. Kruse, Leibniz Univ. Hannover (Germany); K. Sacha,

J. Zakrzewski, Univ. Jagiellonski (Poland) and Jagiellonian Univ. (Poland); M. Lewenstein, Leibniz Univ. Hannover (Germany) and Institut de Ciéncies Fotóniques (Spain); J. J. Arlt, W. Ertmer, Leibniz Univ. Hannover (Germany)

\section{OPTICAL TWEEZERS AND NEAR-FIELD INTERACTIONS}

648309 Exact theory of optical forces of Mie scatterers exposed to high numerical aperture beams examined with 3D photonic force measurements [6483-07]

A. A. R. Neves, A. Fontes, W. L. Moreira, A. A. de Thomaz, D. B. de Almeida, L. C. Barbosa,

C. L. Cesar, State Univ. of Campinas (Brazil)

64830A Refractive multiple optical tweezers for parallel biochemical analysis in micro-fluidics [6483-08]

F. Merenda, J. Rohner, P. Pascoal, J.-M. Fournier, H. Vogel, R. P. Salathé, École

Polytechnique Fédérale de Lausanne (Switzerland)

64830B Scattering of light at micro- and nanostructures of triangular shape [6483-09]

M. R. Gonçalves, A. Siegel, R. Ameling, O. Marti, Univ. of Ulm (Germany)

64830C Time-resolved evanescent wave-induced fluorescence studies of macromolecular adsorption [6483-10]

T. A. Smith, C. A. Scholes, M. L. Gee, Univ. of Melbourne (Australia)

\section{NANOPARTICLE OPTICAL MANIPULATION}

64830D Assembling mesoscopic systems with holographic optical traps [6483-11]

D. G. Grier, S.-H. Lee, Y. Roichman, Y. Roichman, New York Univ. (USA)

64830E Optical manipulation of gold micro and nanoparticles on silicon nitride waveguides: impact of polarization and particle size on gradient forces [6483-12]

S. Gétin, S. Gaugiran, J.-M. Fedeli, CEA Léti - MINATEC (France); J. Derouard, Univ. Joseph Fourier (France)

64830F Three-dimensional holographic ring traps [6483-13]

Y. Roichman, D. G. Grier, New York Univ. (USA)

BEAM SCULPTING

64830 Nonlinear effects in the propagation of short laser pulses in air (Invited Paper) [6483-14]

C. Ruiz, Max Planck Institute for Complex Systems (Germany); J. San Román, I. Sola,

C. Méndez, J. A. Perez, D. Delgado, V. H. Diaz, L. Plaja, I. Arias, L. Roso, Univ. de Salamanca (Spain)

64830I Complex beam sculpting with tunable acoustic gradient index lenses [6483-16]

E. McLeod, C. B. Arnold, Princeton Univ. (USA) 
64830J Structure of cavity modes with general astigmatism [6483-17]

G. Nienhuis, S. J. M. Habraken, Univ. of Leiden (Netherlands)

64830K Engineering of illumination and collection field profiles for single-molecule orientational imaging [6483-18]

Z. Sikorski, L. M. Davis, Univ. of Tennessee Space Institute (USA)

\section{OPTICAL VORTICES I}

$64830 \mathrm{M}$ Generation and diagnosis of focused ultrashort pulses of complex light (Invited Paper) [6483-20]

J. Strohaber, I. Mariyenko, C. J. Uiterwaal, Univ. of Nebraska-Lincoln (USA)

$64830 \mathrm{~N}$ Far field interference measurements of vortex light fields in optical trapping [6483-21]

W. M. Lee, A. E. Carruthers, V. Garcés-Chávez, K. Dholakia, Univ. of St. Andrews (United Kingdom)

648300 Three-dimensional intensity distribution of helico-conical optical beams [6483-22]

C. A. Alonzo, P. J. Rodrigo, I. R. Perch-Nielsen, J. Glückstad, Risø National Lab. (Denmark)

\section{SESSION 9 OPTICAL VORTICES II}

64830Q Laguerre-Gaussian supercontinuum [6483-24]

H. I. Sztul, V. Kartazayev, R. R. Alfano, City Univ. of New York (USA)

64830R Colloidal statistical mechanics in optical vortices [6483-25]

Y. Roichman, D. G. Grier, New York Univ. (USA)

64830T Non-integral vortex structures in diffracted light beams [6483-27]

S. Baumann, E. J. Galvez, Colgate Univ. (USA)

Author Index 
Downloaded From: https://www.spiedigitallibrary.org/conference-proceedings-of-spie on 25 Apr 2023

Terms of Use: https://www.spiedigitallibrary.org/terms-of-use 


\title{
Conference Committee
}

\author{
Symposium Chair \\ Yakov Sidorin, Photineer Technology Group (USA) \\ Symposium Cochair
}

Ali Adibi, Georgia Institute of Technology (USA)

Program Track Chair

Zameer U. Hasan, Temple University (USA)

Conference Chair

David L. Andrews, University of East Anglia Norwich (United Kingdom)

Conference Cochairs

Enrique J. Galvez, Colgate University (USA)

Gerard Nienhuis, Universiteit Leiden (Netherlands)

Program Committee

Nicholas P. Bigelow, University of Rochester (USA)

Wolfgang Ertmer, Liebniz Universität Hannover (Germany)

Jean-Marc R. Fournier, École Polytechnique Fédérale de Lausanne (Switzerland)

Jesper Glückstad, Risø National Laboratory (Denmark)

David G. Grier, New York University (USA)

Lukas Novotny, University of Rochester (USA)

Miles J. Padgett, University of Glasgow (United Kingdom)

Halina H. Rubinsztein-Dunlop, The University of Queensland (Australia)

\section{Session Chairs}

1 Optical Binding and Atom Traps

Enrique J. Galvez, Colgate University (USA)

2 Optical Tweezers and Near-Field Interactions

Gerard Nienhuis, Universiteit Leiden (Netherlands)

3 Nanoparticle Optical Manipulation

Jesper Glückstad, Risø National Laboratory (Denmark) 
4 Beam Sculpting

Jean-Marc R. Fournier, École Polytechnique Fédérale de Lausanne (Switzerland)

5 Special Session

Enrique J. Galvez, Colgate University (USA)

6 Optical Vortices I

Enrique J. Galvez, Colgate University (USA)

7 Optical Vortices II

Gerard Nienhuis, Universiteit Leiden (Netherlands) 


\section{Introduction}

Optical forces on matter often require light fields with special structures. The simplest optical tweezer methods are based on intensity differentials. Beams with vortices or other kinds of phase structures (hollow beams, tailor-made optical traps, sheets of light, and evanescent waves, for example) offer new opportunities for ultrafine control. Through the exchange of linear or angular momentum between light and matter, force fields and torques can be produced that have no counterpart in conventional optical beams.

Structured light affords a host of new methods for guiding the motion of particles. The fabrication of these forms of structured light, their theoretical analysis, and their applications are the unifying features of the articles that are collected in this volume. In fact, it is the close collaboration of fundamental theory, exploratory experiments, and practical applications that makes this field of physics a particularly lively one.

The articles in this volume were presented as papers at a conference in San Jose, which brought together researchers from essentially all continents of the globe. Progress in this field is rapid, and the relevance for various domains such as microand nano-manipulation, and quantum information with photons, gives scope for many stimulating cross-links. The flexibility of methods for sculpting light is large, easily counterbalancing any disadvantages of the intangible nature of photons.

The Conference Chairs and Program Committee are very grateful to all those who contributed to the success of the meeting. We hope that some of the excitement and the stimulation of the field will be conveyed to the readers of the articles in these proceedings.

Gerard Nienhuis

Enrique J. Galvez David L. Andrews 
Downloaded From: https://www.spiedigitallibrary.org/conference-proceedings-of-spie on 25 Apr 2023

Terms of Use: https://www.spiedigitallibrary.org/terms-of-use 